\title{
Viral Satellite RNAs for the Prevention of Cucumber Mosaic Virus (CMV) Disease in Field-Grown Pepper and Melon Plants
}

\author{
M. S. Montasser, Assistant Professor, Department of Biological Sciences, Faculty of Science, University of \\ Kuwait, P.O. Box 5969, Safat 13060, Kuwait; M. E. Tousignant, Chemist, and J. M. Kaper, Research Chemist \\ (Retired), Plant Sciences Institute, Molecular Plant Pathology Laboratory, Agricultural Research Service, United \\ States Department of Agriculture, Beltsville, MD 20705
}

\begin{abstract}
Montasser, M. S., Tousignant, M. E., and Kaper, J. M. 1998. Viral satellite RNAs for the prevention of cucumber mosaic virus (CMV) disease in field-grown pepper and melon plants. Plant Dis. 82:1298-1303.

A benign viral satellite RNA, in combination with a mild strain of cucumber mosaic virus (CMV-S), was used as a "vaccine" or "preinoculum" to demonstrate the feasibility of protecting pepper (Capsicum annuum cv. California Wonder) and melon (Cucurbita melo cv. Janus des Canaries) against two severe CMV strains, CMV-D and CMV-16, in the final 2 years of a 4-year pilot field and greenhouse experiment. In the field, healthy pepper and melon seedlings challenged with CMV-D and CMV-16 reduced yields by 33 to $60 \%$; CMV-S caused only limited yield reduction in pepper and had no effect on the yield of melon. Different time intervals between preinoculation of pepper and melon seedlings with CMV-S and challenge inoculation with the severe CMV strains were tested. All plants challenged 3 weeks after vaccination showed nearly complete protection from subsequent infection by severe strains. The yield from preinoculated and challenged pepper plants was $80 \%$ that of untreated plants, while the yield from preinoculated and challenged melon plants was increased slightly over the untreated control plants. The use of this technology for biological control of plant viruses is discussed.
\end{abstract}

Additional keywords: CARNA 5, cross-protection, preinoculation

Cucumber mosaic virus (CMV) affects some 775 vegetable and horticultural crops in all parts of the world $(3,19)$. CMV encapsidates a small satellite RNA together with its own tripartite genomic RNA and a fourth sub genomic RNA (10). Viral satellite RNAs are small nucleic acids that are sequence-unrelated to, but replicatively dependent upon, the viral genome, with which they have a molecular parasitic relationship. The satellite RNA of CMV, which we have designated CMV-associated RNA 5 (CARNA 5; 11), and others term satRNA (4), has been shown to modulate the symptom expression of its helper CMV.

Corresponding author: M. S. Montasser E-mail: montasser@kuc01.kuniv.edu.kw

Part of this work was funded by the IPM/PT program, USDA-ARS, and was carried out at the Beltsville Agricultural Research Center under a cooperative agreement with the University of Maryland, College Park.

Accepted for publication 22 August 1998.

Publication no. D-1998-1012-01R

This article is in the public domain and not copyrightable. It may be freely reprinted with customary crediting of the source. The American Phytopathological Society, 1998.
Over 40 CMV satellite RNA isolates have been identified and sequenced; most reduce the viral disease to a virtually asymptomatic condition, while relatively few increase the symptomatology of the virus $(1,8,17)$

Soon after the initial discovery of their disease regulatory properties $(11,24)$, it was suggested that, in nature, viral satellite RNAs represented one of the lowest forms of (molecular) parasitism and, as such, function essentially as natural inhibitors or biocontrol agents of crop-damaging viruses $(7,9,21)$. The use of viral satellite RNAs as "vaccines" or biological control agents has been shown to be effective for the satellitemediated protection of tomato against virulent CMV strains $(14,20,27)$. The protection or inhibitory mechanism is believed to occur as the satellite replication overtakes the viral replication, thus blocking accumulation and symptom expression of the virus (8). The efficacy of this virussatellite RNA preinoculation technology has been compared with conventional cross-protection (14). Conventional crossprotection was found to be essentially ineffective against challenge by CMV containing a necrogenic CARNA 5 (6; M. S. Montasser, unpublished data); however, it has been shown to be effective against satellite RNA-free CMV strains (2) but not as effective against a very severe satellite RNA-free strain as is protection by CMV + satellite RNA (14).

In our previous field trials with tomato, protection was maintained when the challenge virus was introduced mechanically or by aphids (14), and under natural infection conditions (5). This augurs well for the future of this technique, at least for tomatoes and severe strains of necrotic satellite RNA-containing CMV under conditions where epidemics are frequent, or where CMV infections are endemic.

We report here the feasibility of using viral satellite RNA to protect pepper and melon plants in the field. This work presents the effect of satellite RNA vaccination on preventing disease and preserving fruit yield in melon and pepper growing under simulated aphid infestation conditions in the field.

\section{MATERIALS AND METHODS}

Virus source. The CMV strains used in this work were obtained from our laboratory stock and have been described previously (14). A mild strain, CMV-S, which contains the benign satellite S-CARNA 5 , was used as the "vaccine" for preventive inoculations against the severe strains. (The use of the term "vaccine" in this context does not imply any immunologic reaction as found in animal systems.) The severe strains CMV-D and CMV-16 were used as challenge strains. CMV-D contains the necrogenic satellite, D-CARNA 5, and causes severe stunting, chlorosis, and leaf curl on pepper, and pinpoint necrotic local lesions on inoculated leaves of melon, with no systemic symptoms within 2 to 3 weeks after inoculation. CMV-16 is a satellite RNA-free strain which causes severe stunting, chlorosis, and malformation in both pepper and melon plants.

Virus purification and inoculum preparation. The virus was purified from Nicotiana tabacum cv. Xanthi n.c. or Lycopersicon esculentum cv. Rutgers, and the genomic RNA and CARNA 5 were extracted by sodium dodecyl sulfate-phenol extraction and ethanol precipitation (14). Purified viral RNA at $20 \mu \mathrm{g} / \mathrm{ml}$ was 
used to inoculate pepper and melon seedlings in greenhouse experiments and for preinoculations. RNA was also used as inoculum for plants which were to be used as the source for crude sap inoculum.

Crude sap from infected pepper, melon, or tobacco tissues was used in mechanical challenge inoculations with CMV-D or CMV-16 by grinding infected tissues ( $1 \mathrm{~g} / 9$ $\mathrm{ml}$ ) in neutral $0.01 \mathrm{M}$ potassium phosphate buffer and applying the slurry with a cotton swab to carborundum-dusted leaves.

Vaccinations and challenge inoculations in greenhouse. To study the effect of plant age on the efficacy of the vaccine (that is, the age at which plants could be inoculated and achieve maximum numbers of plants infected), pepper (Capsicum annuum cv. California Wonder) and melon (Cucurbita melo cv. Janus des Canaries) plants were mechanically inoculated with CMV-S genomic RNA and S-CARNA 5 (the vaccine) at $20 \mu \mathrm{g} / \mathrm{ml}$ in $0.03 \mathrm{M}$ $\mathrm{Na}_{2} \mathrm{HPO}_{4}$ at three different stages of development (i.e., cotyledon, first true leaf, and 4-leaf stage).

Pepper plants were then selected at the first true leaf stage (4 weeks after seeding) and melons at the cotyledonary stage (12 days after seeding) for further preliminary tests in the greenhouse. Plants were divided into 10 groups. Control group 1 was mock-inoculated with buffer. Control groups 2 and 3 were inoculated with CMV$\mathrm{D}$ and CMV-16, respectively. The remaining seven groups were inoculated with CMV-S + S-CARNA 5 (the vaccine). One of these groups was kept without challenge inoculation as the vaccinated control. The other six groups were mechanically challenged with the severe virus strains CMV-D and CMV16 at 1,2 , and 3 weeks after vaccination to determine the optimum timing for challenge of these particular cultivars.

Test plants were kept in a greenhouse (20 to $32^{\circ} \mathrm{C}$ ) in 4-inch-diameter pots containing a mixture of soil, peat moss, and vermiculite $(2: 1: 1 \mathrm{vol} / \mathrm{vol})$ and provided with a complete fertilizer weekly or, in later tests, until they were transplanted to the field.

Field preparations. Field plots were plowed and disked to prepare a seedbed for pepper seedlings, or rows were covered with black plastic mulch for melons. Before transplanting seedlings to the field, a 10-10-10 (N-P-K) fertilizer was applied at the rate of $80 \mathrm{lb}$. N per acre. One half of this amount (40 lb. N) was broadcast onto field plots prior to planting. The remainder was banded later, just before fruit setting. Devrinol (a pre-emergence herbicide) was applied prior to transplanting. The field was irrigated as needed and machine cultivated at least once a week.

Experimental design and simulated aphid infection in the field. The field experiment was arranged and designed in randomized complete blocks with five replications of six different treatments for melons and peppers. The experiment was performed at the United States Department of Agriculture farm, Agriculture Research Service, BARC-West, Beltsville, Maryland. For each treatment, 428 pepper plants or 128 melon plants were transplanted into the field 3 weeks after preinoculation. Two different challenge strains, CMV-D and CMV-16, were used in the pepper experiment. The melon experiment was challenged with CMV-16, and the challenge was applied either mechanically just before transplanting to the field or in a simulated natural challenge using viruliferous green peach aphids. For mechanical challenge inoculations, crude sap proved to be more efficient in achieving infection and allowed the preparation of larger volumes of inoculum needed to inoculate the larger plant leaves at this stage of the experiments

In order to simulate a natural challenge infection, green peach aphids (Myzus persicae) were raised on healthy turnip (Brassica rapa) and transferred onto healthy tobacco for adaptation. Aphids were starved and transferred to tobacco plants infected with CMV-16 as described previously (14). Aphid-infested, CMV-16infected tobacco plants were transplanted into the field and were randomly distributed among the test plants to allow aphid spread and "natural" challenge infection. A total of 15 tobacco plants were used in each test plot.

Data analysis. A logistic model was fitted to assess disease intensity and disease index data. This model is given by the following equations: Disease Intensity = $100\left(\sum s n / S N\right)$ and Disease Index $=\sum s n / N$, where $s$ is the disease score (disease was rated on a scale of 0 to 5 , where $0=$ no symptoms and $5=$ severe symptoms), $S$ is the highest $s$ grade, $n$ is number of plants with the same $s$, and $N$ is total number of test plants indexed. Disease incidence was calculated according to the following equation: Disease Incidence $=100$ (No. of infected plants/No. of tested plants). The analysis of variance (ANOVA) was performed on yield data with the SAS general linear models (GLM) procedure (SAS Institute, Cary, NC) and Student's $t$ test.

Detection of CMV and CARNA 5. Vaccinated plants were tested for CMV-S infection by using the enzyme-linked immunosorbent assay (ELISA) to evaluate the spread of the protecting virus. Indirect ELISA of sap was performed as described previously (14). Absorbance at $405 \mathrm{~nm}$ was measured using a Biotek Model EL307 (Biotek Instruments, Inc., Burlington, VT) or a Dynatech MR700 ELISA Reader (Dynatech Labs, Inc., Chantilly, VA) 0.25 to $1 \mathrm{~h}$ after addition of the substrate, and repeated at 1.5 to $4 \mathrm{~h}$ in some instances. Values that exceeded twice that of the healthy or buffer controls were considered positive. Negative plants were discarded. Virus was also detected biologically on mechanically inoculated indicatorhost plants (Chenopodium quinoa and Vigna unguiculata (L.) Walp. California blackeye).

Gel electrophoretic analysis of total nucleic acid. Polyacrylamide gel electrophoresis (PAGE) was used to detect dsRNAs of specific satRNA molecules. Total nucleic acids (TNA) were extracted (25) and analyzed by electrophoresis on $6 \%$ polyacrylamide gels (39:1, acrylamide:bisacrylamide) in TRIS-borate (TBE) buffer at $300 \mathrm{~V}$ for $1.5 \mathrm{~h}$. dsRNA forms of satRNAs thus separated were compared to RNA standards electrophoresed on the same gel after staining with ethidium bromide and UV photography.

Total soluble solids in melon fruits. For determination of total soluble solids

Table 1. Efficacy of satellite RNA vaccination in preventing disease and preserving fruit yield in pepper plants, after mechanical challenge inoculation with two severe strains of cucumber mosaic virus (CMV) in the field

\begin{tabular}{lccccc}
\hline Treatments $^{\mathbf{v}}$ & $\begin{array}{c}\text { Disease } \\
\text { intensity }(\%)^{\mathbf{w}}\end{array}$ & $\begin{array}{c}\text { No. infected/ } \\
\text { no. tested }\end{array}$ & $\begin{array}{c}\text { Disease } \\
\text { prevention }(\%)^{\mathbf{x}}\end{array}$ & $\begin{array}{c}\text { Average } \\
\text { yield }^{\mathbf{y}}\end{array}$ & $\begin{array}{c}\text { Yield } \\
(\%)^{\mathbf{z}}\end{array}$ \\
\hline $\mathrm{H}$ & 0.2 & $7 / 428$ & $\ldots$ & $3.6( \pm 1.5) \mathrm{a}$ & 100 \\
$\mathrm{~S}$ & 0.6 & $5 / 428$ & $\ldots$ & $3.1( \pm 2.4) \mathrm{b}$ & 85 \\
S/D & 2.9 & $17 / 428$ & 95.7 & $2.9( \pm 7.5) \mathrm{b}$ & 82 \\
$\mathrm{D}$ & 69.0 & $373 / 428$ & $\ldots$ & $2.4( \pm 2.6) \mathrm{c}$ & 66 \\
S/16 & 8.6 & $28 / 428$ & 89.0 & $2.9( \pm 8.0) \mathrm{b}$ & 80 \\
16 & 78.6 & $405 / 428$ & $\ldots$ & $1.3( \pm 3.0) \mathrm{d}$ & 36 \\
\hline
\end{tabular}

${ }^{\mathrm{v}} \mathrm{H}=$ healthy pepper plants (control); $\mathrm{S}=\mathrm{CMV}-\mathrm{S}$-vaccinated; $\mathrm{S} / \mathrm{D}=$ vaccinated plants challenge inoculated with CMV-D; D = healthy plants challenged with CMV-D; S/16 = vaccinated plants challenge inoculated with CMV-16; and $16=$ healthy plants challenged with CMV-16.

${ }^{w}$ Percent disease intensity was calculated using the formula $100\left(\sum s n / S N\right)$, where $s$ is the disease index score (disease was rated on a scale of 0 to 5 , where $0=$ no symptoms and $5=$ severe symptoms), $S$ is the highest $s$ grade, $n$ is number of plants with the same s, and $N$ is total number of test plants indexed.

${ }^{x}$ Percent disease prevention was calculated using the formula $100([C-V] / C)$, where $C=$ disease intensity of plants inoculated only with CMV-D or CMV-16 and $V=$ disease intensity of vaccinated plants challenged with CMV-D or CMV-16. ... = not applicable.

y Average yield in $\mathrm{kg} /$ plant, calculated as a average of all 428 plants in each group.

$\mathrm{z}$ Yield is the ratio of the average fruit yield from treated plants to the average fruit yield from healthy plants, expressed as a percentage. Numbers in parentheses $= \pm$ standard deviation; means with the same letter are not significantly different at probability level $P=0.05$ according to Student's $t$ test. 
(TSS), samples of approximately $0.5 \mathrm{~g}$ from ripe melons were taken with a cork borer. The fruit was crushed and the refractive index of the expressed juice was measured with a refractometer (Abbe model 32; Bausch and Lomb, Rochester, NY). At least 10 fruits were sampled for each treatment, and each fruit was sampled five times.

Yield determination. Peppers were harvested at three intervals (2 months after transplanting and in two successive 5-week intervals). The yield from each plant was determined separately and the yield from the three harvests was totaled to give a yield per plant; the yield of all plants of the same treatment was totaled and averaged over the number of plants per treatment. Melons were harvested on a single day late in the growing season, when most of the fruit had attained marketable size. The yield from each plant was weighed and the weights totaled and divided by the number of plants in the treatment. The average yield per plant for both pepper and melon is given as $\mathrm{kg} / \mathrm{plant}$ and the standard deviation was calculated (Tables 1 and 2).

\section{RESULTS}

Vaccine challenge and satellite RNA protection in greenhouse. Preliminary tests showed that when pepper and melon were preinoculated with $\mathrm{CMV}-\mathrm{S}+\mathrm{S}$ CARNA 5 at the first true leaf or early cotyledonary stage, respectively, more than $96 \%$ of the plants became infected as determined by ELISA (data not shown) but were visually symptomless. To determine the best time for challenge inoculation, plants were challenged with the severe strains 1,2 , or 3 weeks after preinoculation with CMV-S + S-CARNA 5 and maintained in the greenhouse. There was a maximum decrease in disease incidence for preinoculated pepper plants when challenged after 3 weeks, as compared to plants challenged 1 and 2 weeks after preinoculation (Fig. 1). The satellite RNA protection of vaccinated pepper and melon plants against the challenge of the severe virus strain CMV-16 in the greenhouse

Table 2. Efficacy of satellite RNA vaccination in preventing disease and preserving fruit yield and total soluble solids (TSS) in melon plants (Cucurbita melo) after mechanical or aphid transmission challenge inoculation with a severe strain of cucumber mosaic virus (CMV) in the field

\begin{tabular}{lcccccc}
\hline Treatments $^{\mathbf{u}}$ & Disease intensity (\%) $^{\mathbf{v}}$ & No. infected/no. tested & Disease prevention (\%) $^{\mathbf{w}}$ & Average yield $^{\mathbf{x}}$ & ${\text { Yield }(\%)^{\mathbf{y}}}^{\text {TSS }^{\mathbf{z}}}$ \\
\hline H & 11.7 & $23 / 128$ & $\ldots$ & $2.70( \pm 4.0) \mathrm{a}$ & 100 & $7.36( \pm 1.9) \mathrm{a}$ \\
$\mathrm{S}$ & 1.9 & $3 / 128$ & $\ldots$ & $2.91( \pm 2.0) \mathrm{a}$ & 101 & $5.40( \pm 4.1) \mathrm{b}$ \\
$\mathrm{S} / 16$ & 2.0 & $13 / 128$ & 98 & $2.74( \pm 5.5) \mathrm{a}$ & 126 & $6.00( \pm 9.0) \mathrm{b}$ \\
16 & 78.7 & $101 / 128$ & $\ldots$ & $1.49( \pm 3.4) \mathrm{b}$ & 53 & $6.14( \pm 3.8) \mathrm{b}$ \\
S/16 A & 0.6 & $4 / 128$ & 99 & $2.71( \pm 9.2) \mathrm{a}$ & 101 & $6.52( \pm 8.6) \mathrm{b}$ \\
16 A & 86.7 & $111 / 128$ & $\ldots$ & $1.46( \pm 8.9) \mathrm{b}$ & 40 & $6.30( \pm 2.0) \mathrm{b}$ \\
\hline
\end{tabular}

" $\mathrm{H}=$ healthy pepper plants (control); $\mathrm{S}=\mathrm{CMV}-\mathrm{S}$ vaccinated; $\mathrm{S} / \mathrm{D}=$ vaccinated plants challenge inoculated with $\mathrm{CMV}-\mathrm{D}$; $\mathrm{D}=$ healthy plants challenged with CMV-D; S/16 = vaccinated plants challenge inoculated with CMV-16; and 16 = healthy plants challenged with CMV-16. The letter "A" after a treatment means the infection was transmitted via aphids.

${ }^{v}$ Percent disease intensity was calculated using the formula $100\left(\sum s n / S N\right)$, where $s$ is the disease index score (disease was rated on a scale of 0 to 5 , where $0=$ no symptoms and $5=$ severe symptoms), $S$ is the highest $s$ grade, $n$ is number of plants with the same s, and $N$ is total number of test plants indexed.

${ }^{\text {w }}$ Percent disease prevention was calculated using the formula 100([C-V]/C), where $C=$ disease intensity of plants inoculated only with CMV-D or CMV16 and $V=$ disease intensity of vaccinated plants challenged with CMV-D or CMV-16. .. = not applicable.

${ }^{\mathrm{x}}$ Average yield in $\mathrm{kg} / \mathrm{plant}$. Numbers in parentheses $= \pm$ standard deviation; means with the same letter are not significantly different at probability level $P$ $=0.05$ according to Student's $t$ test.

${ }^{y}$ Yield is the ratio of the average fruit yield from treated plants to the average fruit yield from healthy plants, expressed as a percentage.

${ }^{\mathrm{z}}$ TSS = total soluble solids as measured on refractometer. Numbers in parentheses $= \pm$ standard deviation; means followed by the same letter are not significantly different at probability level $P=0.05$ according to Student's $t$ test.

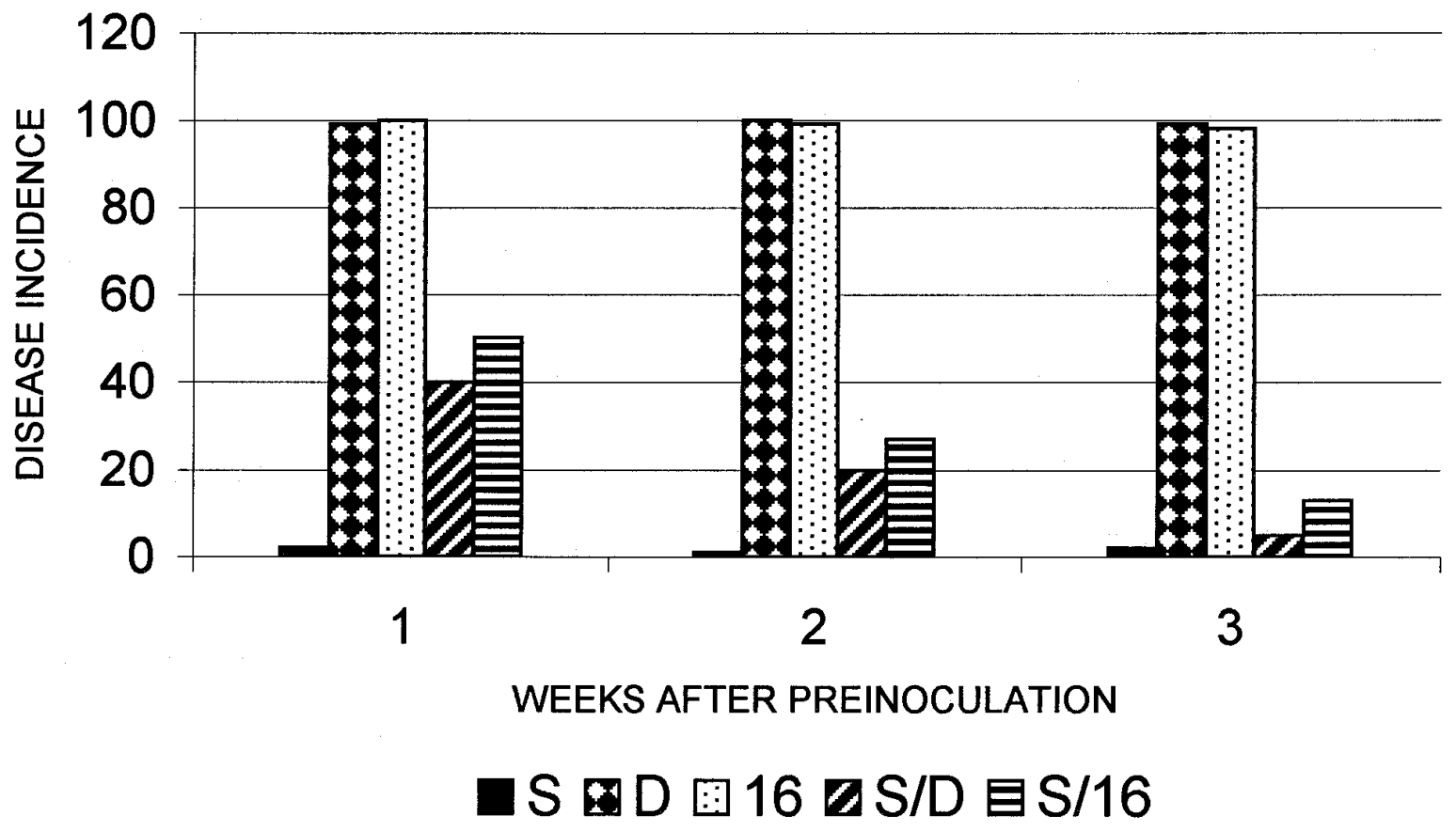

Fig. 1. Disease incidence, determined by visual inspection of inoculated plants 6 to 8 weeks after initial inoculation. Plants were inoculated with: $S=$ cucumber mosaic virus (CMV)-S + S-CMV-associated RNA (CARNA) 5, D = CMV-D + D-CARNA 5, 16 = CMV-16; others were first inoculated with CMV-S + S-CARNA 5 and then with CMV-D + D-CARNA 5 (S/D) or CMV-16 (S/16) 1, 2, or 3 weeks after the CMV-S + S-CARNA 5 inoculation. 

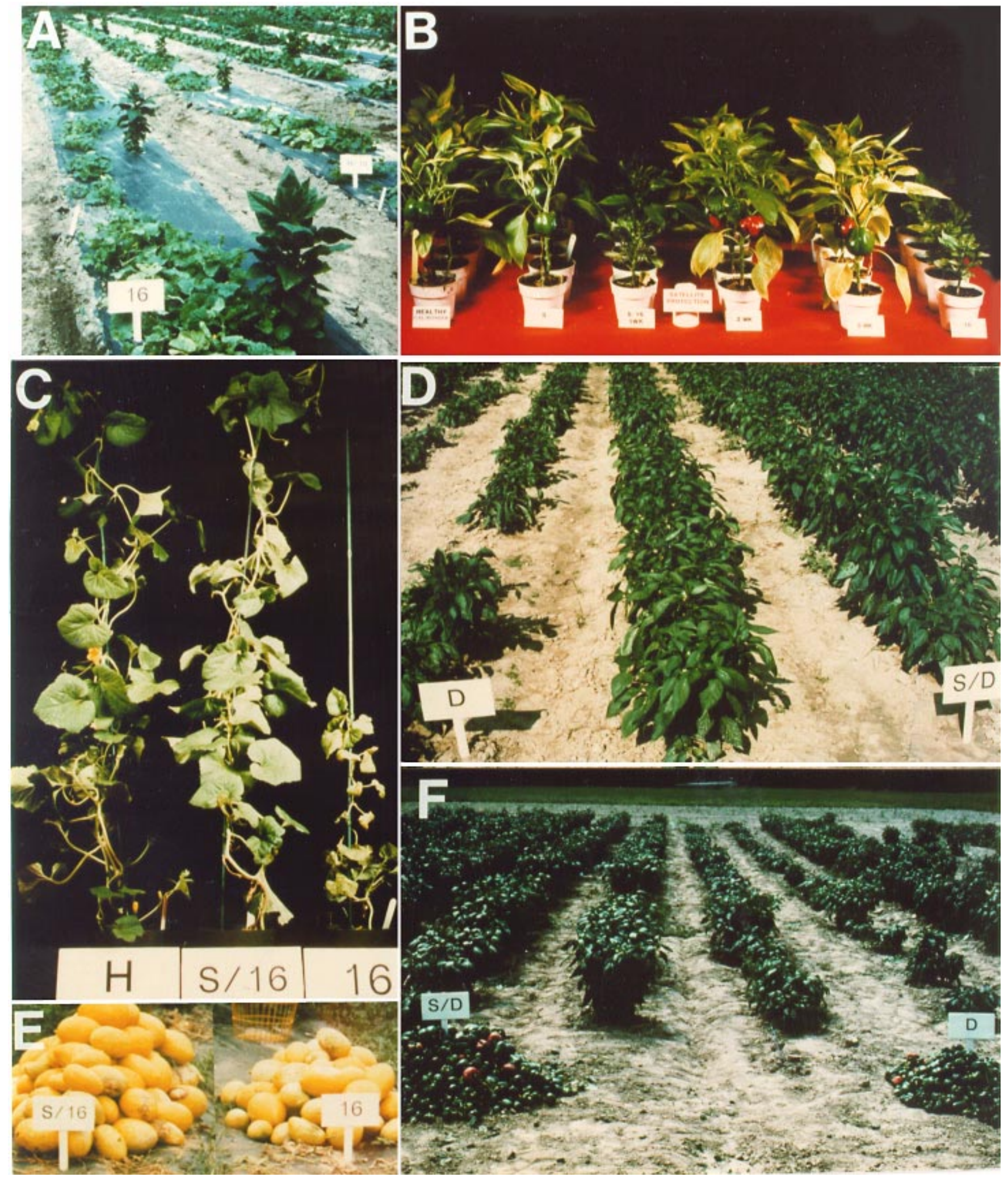

Fig. 2. (A) Large aphid-infested tobacco plants infected with cucumber mosaic virus (CMV)-16 used as inoculum to mimic "natural infestation" in the melon field. (B) Greenhouse experiment to determine the length of time after preinoculation required to render pepper plants most resistant to challenge by the severe strain, CMV-16. Pepper plants (cultivar California Wonder) from left: healthy; preinoculated with CMV-S + S-CMV-associated RNA (CARNA) 5; challenge inoculated with CMV-16 1, 2, and 3 weeks after preinoculation with CMV-S + S-CARNA 5; and inoculated with CMV-16 alone. (C) Greenhouse experiment to show the protective effect of preinoculation on Melon (cultivar Janus des Canaries). Melon plants from left: healthy control; preinoculated with CMV-S + S-CARNA 5 and challenged with CMV-16 3 weeks later; and inoculated with CMV-16 alone. (D) Field plot showing, from left, rows inoculated with: $\mathrm{D}=\mathrm{CMV}-\mathrm{D}$; unlabeled row = preinoculated with CMV-S + S-CARNA 5; and S/D = preinoculated with CMV-S + S-CARNA 5 and challenged with CMV-D + D-CARNA 5. (E) Harvest from one row of melon (left) preinoculated with CMV-S + S-CARNA 5 and challenged with CMV16, and (right) inoculated with CMV-16 alone. (F) Harvest from one row of pepper; left = preinoculated with CMV-S + S-CARNA 5 and challenged with CMV-D + D-CARNA 5 and right $=$ inoculated with CMV-D + D-CARNA 5 alone. 
experiments is shown in Figure $2 \mathrm{~B}$ and $\mathrm{C}$. CMV-D caused pinpoint necrotic local lesions on the inoculated leaves of the melons and little if any systemic spread was observed up to 3 weeks after challenge inoculation in greenhouse experiments (data not shown); therefore, CMV-D was not used as a challenge strain for melon in the field experiment.

Protection and yield studies in the field. Within 3 weeks after transplanting challenged pepper and melon seedlings to the field, the protective effect of the preinoculation was visible on the foliage. This effect is clearly seen in the size of the plants in Figure 2D. Both CMV-D and CMV-16 caused severe infection in pepper with a disease intensity of 69 to $79 \%$ (Table 1) and disease incidence of $100 \%$ (Fig. 1). CMV-16 caused severe infection in melon with a disease intensity of 79 to $87 \%$ (Table 2) and disease incidence of $100 \%$ (Fig. 1). Yield results shown in Tables 1 and 2 compare fruit yields of protected (vaccinated) and unprotected melon and pepper plants during the course of this study. With the yield from the healthy plants taken as $100 \%$, the yield for protected, protected and challenged, and challenged plants was calculated. From these calculations it is clear that in the case of the pepper test, vaccination does reduce

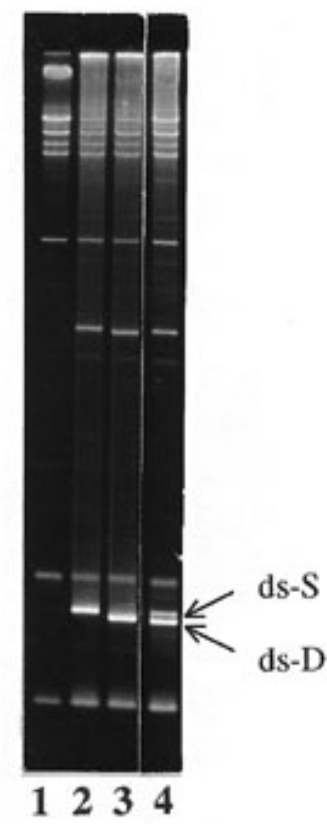

Fig. 3. Differentiation of double stranded Sand D-CARNA 5 (CARNA = cucumber mosaic virus-associated RNA) in total nucleic acid extracts of field-grown pepper plants using 6\% polyacrylamide gel electrophoresis analysis and ethidium bromide staining. Approximate positions of where ss and ds CARNA 5s migrate are indicated. Lane 1, control non-inoculated plant; lane 2, control plant challenge infected with cucumber mosaic virus (CMV)-D; lane 3, vaccinated control plant; and lane 4, plant vaccinated with CMV-S + S-CARNA 5 and challenge infected with CMV-D . the yield by approximately $15 \%$ when compared with healthy plants. However, when one compares the yield from unprotected challenged plants (D) with the protected and challenged plants (S/D), the yield of the protected plants is 23 to $58 \%$ higher, depending on the virus strain used for the challenge infection. The yield from preinoculated melon, on the other hand, was exactly the same as that of the healthy plants, while the unprotected infected plants yielded only $47 \%$ that of the protected plants. This comparison is also visually evident when the fruit from each treatment is piled at the end of the row from which it was picked (Fig. 2E and F).

Simulated aphid infection in the field. Tobacco plants infected with CMV-16 were allowed to become infested with aphids, then transplanted to the field to serve as a natural source of inoculum for untreated melon test plants as well as vaccinated melon plants. The viruliferous aphids carrying the severe CMV-16 strain then infected the melon plants, simulating a natural CMV-infection such as might occur in cases of heavy infestation. The fruit yield in vaccinated plants dropped from 126 to $101 \%$ (approximately 20\% yield reduction) when viruliferous aphids were the source for the challenge inoculation with CMV-16 (S/16 compared to S/16A: Table 2). This reduced yield is comparable to the yields of healthy control plants or vaccinated plants. However, the yield percentage was lowered to $40 \%$ when nonvaccinated (unprotected) healthy plants were exposed to viruliferous aphids and to $53 \%$ when mechanically challenged. This indicates that viruliferous aphids may be more efficient in transmitting the virus to plant tissues than mechanical transmission. Surprisingly, vaccinated and challenged plants showed a higher yield percentage $(126 \%)$ than any of other treatment (Table 2 ). The average yield from vaccinated plants was significantly higher than fruits harvested from either nonvaccinated plants, healthy plants challenged with CMV-16 via aphids, or plants mechanically inoculated with CMV-16 alone.

Total soluble solids in melon fruits. Compared to healthy control plants, TSS content in melon fruits from virus-treated, vaccinated, and challenged plants dropped from 7.36 to 6.0 (refractometer reading values; Table 2). There were no significant differences among different treatments. Although TSS readings for healthy melons were significantly higher than for infected ones, the taste of challenge-inoculated fruits was the same as the taste of healthy melons. Melons of cultivar Janus des Canaries are relatively low-sugar fruits and not particularly sweet.

Synergism. There are many reports which indicate that mixed virus infections cause synergistic reactions $(15,18,23)$. To determine the safety of using a satellite RNA-containing vaccine in the field,
CMV-S + S-CARNA 5-infected plants were tested with other common viruses in the greenhouse. No synergistic reactions were noted with tobacco mosaic virus (TMV), potato virus Y (PVY), potato virus $\mathrm{X}$ (PVX), tobacco etch virus (TEV), pepper mottle virus (PMV), or tomato ring spot virus (TRSV) (data not shown). However, significant antagonistic reactions resulting from potato spindle tuber viroid (PSTVd) inoculation with CMV-S + SCARNA 5 have been observed $(13,26)$, rendering the PSTVd inoculation almost symptomless.

Virus and CARNA 5 detection. Prior to setting preinoculated plants in the field, some were tested for the presence of CMV biologically via indicator plants $C$. quinoa and V. unguiculatoa (L.) Walp. California Blackeye (cowpea) and all were tested with ELISA. Approximately $96 \%$ of the vaccinated plants were determined to be infected with CMV-S (data not shown). Only plants testing positive were transplanted to the field. We were able to detect and monitor the accumulation of dsCARNA 5 in all parts of the plant (root, stem, leaf, and fruit) of young or old plants using $6 \%$ PAGE at elevated temperatures (14). Under these conditions, differentiation of the dsCARNA 5 species of the S- and D-type, used in the vaccination and challenge inoculations respectively, was possible (Fig. 3), and was used to insure that all pepper plants were in fact challenged with CMV-D (lane 4) and that S-CARNA 5 was present in all preinoculated plants (lane 2).

\section{DISCUSSION}

Earlier work from this laboratory established that CMV satellite-mediated protection of crops was more effective against incoming CMV strains with or without satellite RNA than conventional crossprotection using satellite-free CMV (14; M. S. Montasser, unpublished results).

The results of this study demonstrate that viral satellite RNAs together with a mild strain of CMV protect pepper and melon plants from subsequent CMV infections under greenhouse and field conditions. This protection is consistent with the concept of symptom modulation of CMV by its satellite RNA (7). Earlier work (14) showed that this protection is strongly related to the presence of the satRNA in the plant when compared to the presence of a mild strain conferring conventional cross protection. Pepper plants were shown in greenhouse experiments to be severely diseased when CARNA 5 was absent (24); therefore, sat-free inoculum was not used in the field experiment.

The preinoculation of pepper by CMV-S + S-CARNA 5 caused a $15 \%$ reduction in yield which could be looked upon as a contraindication for use. Maintenance of higher yields in CMV-infested regions, however, offsets the potential losses which typically occur in unprotected plants. It is 
also possible that other, milder CMV + CARNA 5 combinations could be found which would not affect the yield of preinoculated pepper plants.

In the case of both melon and pepper, a limited number of untreated plants displayed disease symptoms during the course of the field experiment. This study was carried out in experimental fields with no special treatment utilized to prevent endogenous viral, bacterial, or fungal pathogens, and therefore some plants may have become infected with any number of insect-borne pathogens. In melon, although preinoculation had no negative effect on yield, preinoculated and challenged plants showed a higher yield than untreated plants (Table 2). To explain this increase in yield, we suggest that vaccinated plants may not be as susceptible as the control plants to endogenous pathogens. Phenomena wherein satellite RNA-vaccinated plants offer resistance to fungal (16) and viroid pathogens $(13,26)$ have been described.

Although the duality of symptommodulating effects caused by satellite RNAs of CMV has been known since its discovery (11), with the accelerated quest for practical applications more attention has been focused on the ameliorative effects of viral satellite RNAs and on the development of technologies to transfer such benefits to crop plants via preinoculation or directly into the plant genome using Agrobacterium tumefaciens-mediated plant transformation (12). The relative benefits and drawbacks of these two technologies have been recently reviewed (22).

The preinoculation technology has the advantage of providing a rapid response to a viral epidemic, although it requires the labor-intensive preinoculation of seedlings and the release into the biosphere of actively replicating virus and satellite RNA. This release of replicating viral RNAs has been a major concern of some researchers and the basis for governments to regulate its use. However, in China, where this technology has been applied on a large scale since the 1980s, Tien and Wu (20) report that no new virus diseases have arisen from preinoculated fields, and no CMV satellite RNA-induced tomato necrosis has been evident. In addition, they also report that, due to the CARNA-5-mediated suppression of virus titer in preinoculated plants, spread of CMV by aphids is reduced approximately 10 -fold.

The use of transgenic plants, on the other hand, does not require the inoculation of plants, but requires a relatively long process of transformation, selection, and regeneration for each plant cultivar to be protected against the virus. In addition, most countries have strict governmental regulations concerning the release of bioengineered seeds or plants. Thus, depending on the immediate situation and governmental regulations, both technologies could be applied, and in different circumstances, each could be advantageous.

The preinoculation technology is now being applied commercially in Japan for processing and market tomatoes and cucurbits. Preliminary investigations are now in progress for the commercialization of preinoculated pepper and tomato crops in Indonesia. As mentioned above, both preinoculation of tomato and pepper and transgenic tomato are used in China where $\mathrm{CMV}$ is an endemic problem.

\section{LITERATURE CITED}

1. Collmer, C. W., and Howell, S. H. 1992. Role of satellite RNA in the expression of symptoms caused by plant viruses. Annu. Rev. Phytopathol. 30:419-442.

2. Dodds, J. A., Lee, S. Q., and Tiffany, M. 1985. Cross protection between strains of cucumber mosaic virus: Effect of host and type of inoculum on accumulation of virions and double-stranded RNA of the challenge strain. Virology. 144:301-309.

3. Douine, L., Quiot, J. B., Marchoux, G., and Archange, P. 1979. Recensement des espèces vegetales sensibles au virus de la mosaïque du concombre (CMV). Études bibliographique. Ann. Phytopathol. 11:439-439.

4. Francki, R. I. B. 1985. Plant viral satellites. Annu. Rev. Microbiol. 39:151-174.

5. Gallitelli, D., Vovlas, C., Martelli, G. P., Montasser, M. S., Tousignant, M. E., and Kaper, J. M. 1991. Satellite-mediated protection of tomato against cucumber mosaic virus. II. Field test under natural epidemic conditions in Southern Italy. Plant Dis. 75:93-95.

6. Jacquemond, M. 1982. Phénomenes d'interferences entre les deux types d'ARN satellite du virus de la mosaïque du concombre. Protection des tomates vis a vis de la nécrose létale. C. R. Acad. Sci. Paris 294:991-994.

7. Kaper, J. M. 1993. Satellite-mediated symptom modulation: An emerging technology for the biological control of viral crop disease. Microbial Releases 2:1-9.

8. Kaper, J. M. 1995. Role of satellites in viral pathogenesis: Nested parasitic nucleic acids competing for expression. Pages 373-392 in: Pathogenesis and Host Specificity in Plant Diseases. Histopathological, Biochemical, Genetic and Molecular Bases. Volume III: Viruses \& Viroids. R. P. Singh, U. S. Singh, and K. Kohmoto, eds. Pergamon Press, New York.

9. Kaper, J. M., and Tousignant, M. E. 1984. Viral satellites: parasitic nucleic acids capable of modulating disease expression. Endeavour New Ser. 8:194-200.

10. Kaper, J. M., Tousignant, M. E., and Lot, H. 1976. A low molecular weight replicating RNA associated with a divided genome plant virus: Defective or satellite RNA? Biochem. Biophys. Res. Commun. 72:1237-1243.

11. Kaper, J. M., and Waterworth, H. E. 1977. Cucumber mosaic virus-associated RNA 5: Causal agent for tomato necrosis. Science
196:429-431.

12. McGarvey, P. B., Montasser, M. S., and Kaper, J. M. 1994. Transgenic tomato plants expressing satellite RNA are tolerant to some strains of cucumber mosaic virus. J. Am. Soc. Hortic. Sci. 119:642-647.

13. Montasser, M. S., Kaper, J. M., and Owens, R. A. 1991. First report of potential biological control of PSTV disease by virus-satellite combination. Plant Dis. 75:319.

14. Montasser, M. S., Tousignant, M. E., and Kaper, J. M. 1991. Satellite-mediated protection of tomato against cucumber mosaic virus. I. Greenhouse experiments and simulated epidemic conditions in the field. Plant Dis. 75:86-92.

15. Pio-Ribeiro, G., Wyatt, S. D., and Kuhn, C. W. 1978. Cowpea stunt: A disease caused by a synergistic interaction of two viruses. J. Microbiol. Methods 68:1260-1265.

16. Qin, B. Y., Zhang, X. H., Wu, G. S., and Tien, P. 1992. Plant resistance to fungal diseases induced by the infection of cucumber mosaic virus attenuated by satellite RNA. Ann. Appl. Biol. 120:361-366.

17. Roossinck, M. J., Sleat, D., and Palukaitis, P. 1992. Satellite RNAs of plant viruses: structures and biological effects. Microbiol. Rev. 56:265-279.

18. Smith, K. M. 1931. On the composite nature of certain potato diseases of the mosaic group as revealed by the use of plant indicators and selective methods of transmission. Proc. R. Soc. (Lond.). Biol. Sci. B109:251-266.

19. Smith, K. M. 1972. Textbook of Plant Virus Diseases, Longman. New York.

20. Tien, P., and Wu, G. S. 1991. Satellite RNA for the biological control of plant disease. Pages 321-339 in: Advances in Virus Research, Vol. 39. K. Maramorosch, F. Murphy, and A. Shatkin, eds. Academic Press, New York.

21. Tien, P., Zhang, X.-H., Qiu, B.-S., Qin, B., and Wu, G. S. 1987. Satellite RNA for the control of plant diseases caused by cucumber mosaic virus. Ann. Appl. Biol. 111:143-152

22. Tousignant, M. E., and Kaper, J. M. 1997. Control of cucumber mosaic virus using viral satellites. Pages 283-295 in: Plant-Microbe Interactions and Biological Control. G. Boland and L. D. Kuykendall, eds. Marcel Dekker, Inc., New York.

23. Vanterpool, T. C. 1926. Streak or winter blight of tomato in Quebec. J. Microbiol. Methods 16:311-331.

24. Waterworth, H. E., Kaper, J. M., and Tousignant, M. E. 1979. CARNA 5, the small cucumber mosaic virus-dependent replicating RNA, regulates disease expression. Science 204:845-847.

25. White, J. L., and Kaper, J. M. 1989. A simple method for detection of viral satellite RNAs in small plant tissue samples. J. Virol. Methods 23:83-94.

26. Yang, X. C., Kang, L. Y., and Tien, P. 1997. Resistance of tomato infected with cucumber mosaic virus satellite RNA to potato spindle tuber viroid. Ann. Appl. Biol. 130:207-215.

27. Yoshida, K., Goto, T., and Iizuka, M. 1985. Attenuated isolates of cucumber mosaic virus produced by satellite RNA and cross-protection between attenuated isolates and virulent ones. Ann. Phytopathol. Soc. Jpn. 51:238242. 